\title{
THE DIFFICULTIES OF DIAGNOSTICS OF THE TUBERCULOSIS AND LUNG CANCER COMBINATION
}

\section{Levin G.A.1, Gavrilov P.V.1, Mosina N.V.1,2, Mosin I.V.3, Sokolovich E.G.1}

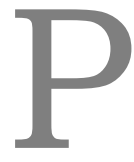

urpose. Using the example of a clinical case to show the difficulty of differential diagnosis of lung tumors and tuberculosis, especially in coexistence.

Materials and methods. The clinical observation of a combination of tuberculosis and typical carcinoid of lower lobe of left lung at the same locus is given.

Results. The current clinical observation clearly demonstrates the difficulties of diagnostics of tuberculosis and lung cancer in coexistence, also a demand of additional diagnostic actions for a valid verification of diagnosis in the current clinical case is shown.

Conclusion. Combination of tuberculosis and lung cancer remains an up-to-date controversial issue in medical community. Difficulties in diagnosing due to the possibility of these diseases' manifestation in poor symptoms and similarity of the x-ray patterns, as well as changes in the concepts of coexistence and mutual influence of these pathologies encourage interest in finding and choosing new optimal and effective diagnostic methods.

Keywords: neoplasm of the lung, lung mass, tuberculosis.

Corresponding author: Gavrilov P.V., e-mail: spbniifrentgen@mail.ru

For citation: Levin G.A., Gavrilov P.V., Mosina N.V., Mosin I.V., Sokolovich E.G. The difficulties of diagnostics of the tuberculosis and lung cancer combination. REJR 2020; 10(1):252 256. DOI:10.21569/2222-7415-2020-10-1-252-256.
Статья получена:
02.02.20
Статья принята:
18.02.20

\section{САОЖНОСТИ АИАГНОСТИКИ СОЧЕТАНИЯ ТУБЕРКУАЕЗА И РАКА АЕГКОГО}

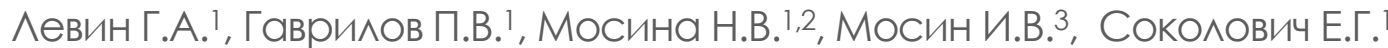

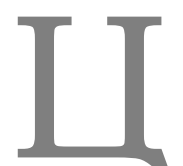

ель. На примере клинического случая показать сложность дифференциальной диагностики опухоцей мегких и туберкулеза, особенно в случае сочетанного поражения

Материалы и методы. Приведено клиническое наблюдение: сочетание туберку-

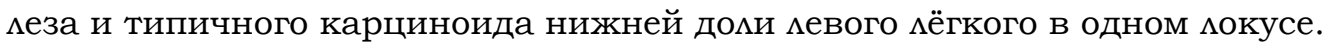

Результаты. Данное клиническое наблюдение наглядно отражает сложности диагностики сочетанного течения туберкулеза и рака мегких, а также показало необходимость дополнительных диагностических мероприятий с целью достоверной верификации диагноза в данном конкретном клиническом случае.

Заключение. Сочетанное течение туберкулёза и рака мёгких остаётся актуальным дискуссионным вопросом в медицинском сообществе. Трудности в постановке диагноза, обусловленные возможностью проявления данных заболеваний скудной симптоматикой и схожестью рентгенологической картины, а также изменение концепций сосуществования и взаимного влияния этих патологий, побуждают интерес для поиска и выбора новых оптимальных и эффективных методик диагностики.

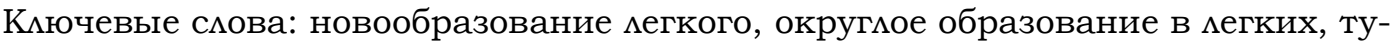
беркулез.

Контактный автор: Гаврилов П.В., e-mail:spbniifrentgen@mail.ru.
1 - St. Petersburg State Research Institute of Phthisiopulmonology. 2 - Academician I.P. Pavlov First St. Petersburg State Medical University.

3 - St. Petersburg Clinical Research Center of Specialized Types of Care (Oncology).

Saint Petersburg, Russia
1 - ФГБУ “СанктПетербургский научноисследовательский институт фтизиопульмонологии" Минздрава России. 2 - ФГБОУ ВО «Первый Санкт-Петербургский государственный медицинский университет им. И.П. ПавАова" 3 - ГБУЗ «СанктПетербургский кАинический научнопрактический центр специализированных видов медицинской помощи (онкологический)". г. Санкт-Петербург, Россия. 
Для иитирования: Аевин Г.А., Гаврилов П.В., Мосина Н.В., Мосин И.В., Соколович Е.Г. Сложности диагностики сочетания туберкулеза и рака легкого. REJR 2020; 10(1):252-256. DOI: 10.21569/2222-7415-2020-10-1-252-256.
Received:
02.02.20
Accepted:
18.02.20

I

\section{ntroduction.}

Round masses in lungs are one of the most frequent findings detected by fluorographic screening especially in populations with a high risk of tuberculosis and lung cancer [1,

2].

Nowadays the objects of radiology are not only to indicate the foci in lungs, but also to reveal their quantitative and qualitative characteristics, as well as determine a potential malignancy of these findings $[3,4]$.

The current diagnostics problem of such diseases as tuberculosis and lung cancer coexistence is timely significant at this stage of development of medicine. In most cases, the basis of diagnostics problems could be a symptomless clinical course of these diseases. It is also important to take into account such a cause as a blurred clinical picture against the background of the similar radiological changes which demand special cau- tion of both physician and radiologist $[5,6]$.

The current clinical observation clearly demonstrates the diagnostic difficulties of the coexistence of tuberculosis and lung cancer.

Clinical case.

Changes in the lungs of a 66-year-old patient were detected during a routine preventive examination. On chest x-ray (Fig. 1.) in 2 projections (posteroanterior (PA) and left lateral) in S8 of the left lung a solid type with clear bumpy contours is determined, without foci in the surrounding tissue or signs of cavities. At the time of the preventive examination, the patient did not submit any complaints.

The patient was consulted by a phthisiologist - no convincing evidence on behalf of tuberculosis was obtained, an oncologist's consultation and CT scan of chest was recommended. The patient was sent to the oncology center to follow-up examination and treatment.

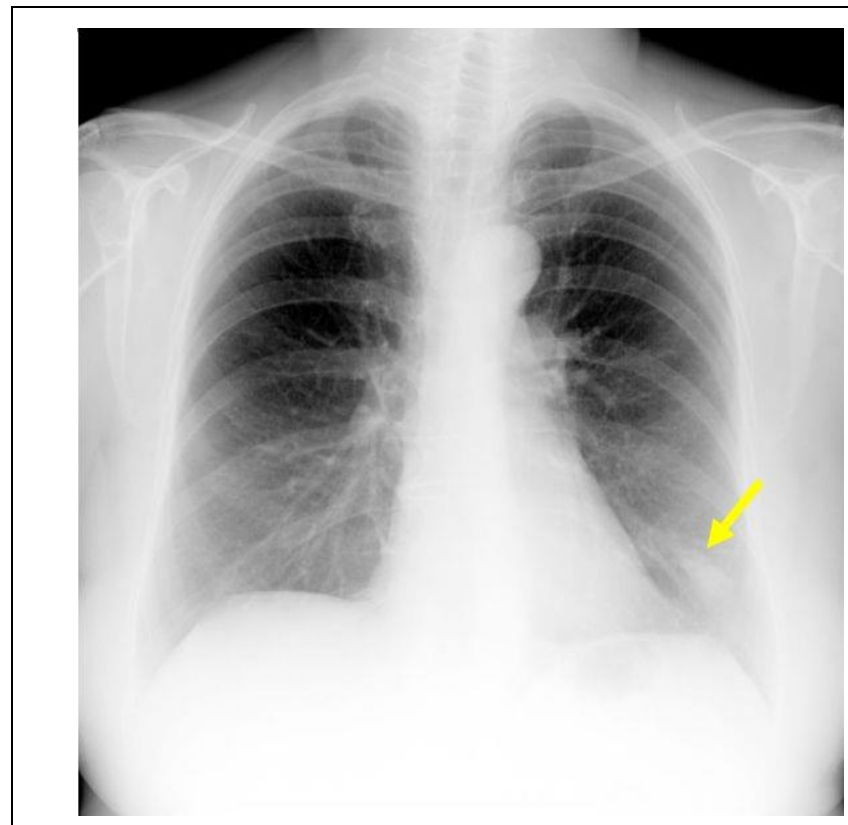

Fig. 1 a (Рис. 1 a)

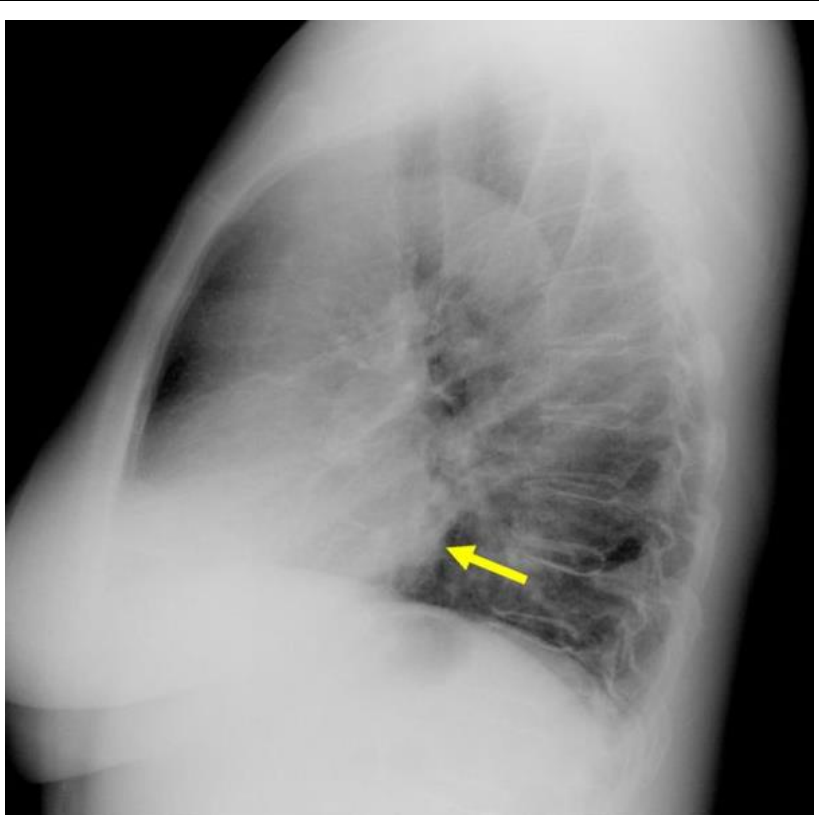

Fig. 1 b (Рис. 1 б)

\section{Fig. 1. Chest X-ray (posteroanterior (PA) and left lateral).}

Lung mass is determined in S8 of the left lung (arrow), a solid type, without a cavity. The surrounding lung tissue is not changed.

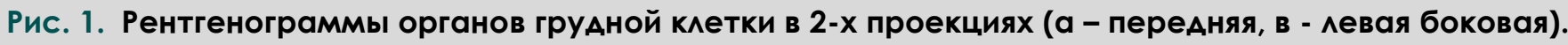

B S8 ^евого мегкого определяется образование (стрелка) солидного типа с четкими бугристыми контурами, без очагов в окружающей ткани и признаков деструкции. 
To clarify the structure of the lung mass a computed tomography of the chest organs was performed (Fig.2). Computed tomography visualized a solid type of left lung mass in S8 with dimensions of $38 \times 22 \mathrm{~mm}$, with uneven contours and areas of reduced density in the structure. There were no signs of calcification in the structure of the mass or destruction zones. In addition singular heavy bands to pleura were determined. The foci and an infiltration in other parts of the lung were not found. Data suggestive of node enlargement in thorax were not obtained. of specific inflammation reactivation (activity 3 grade, $\mathrm{AFB}(+))$. To confirm the combination of tuberculosis with cancer, immunophenotyping was performed: a typical carcinoid tumor of the lower lobe of the left lung (Ki67-1\%) was revealed.

The patient was sent to an anti-TB dispensary for the course of anti-TB therapy at the place of residence for dispensary observation. There were no signs of a recurrence of tuberculosis during the control examination against the background of anti-tuberculosis therapy.

Discussion.

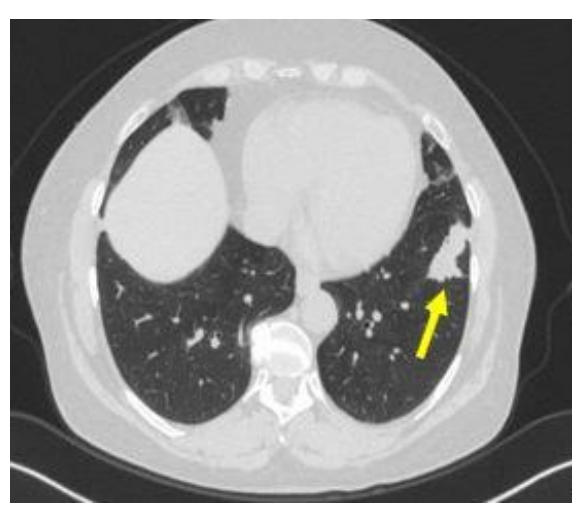

Fig. 2 a (Рис. 2 a)

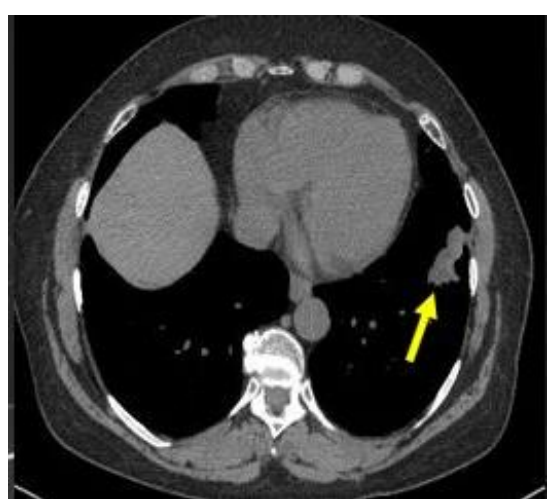

Fig. 2 b (Рис. 2 б)

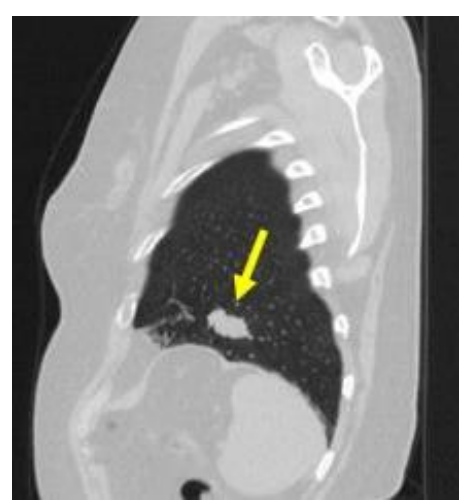

Рис. 2 с (Fig. 2 в)

\section{Fig. 2. MSCT, chest.}

In $\mathrm{S} 8$ of the left lung, a solid mass of irregular shape (arrow), $38 \mathrm{~mm}$ in size, of an inhomogeneous structure due to low-density areas with uneven external contours is determined.

\section{Рис. 2. МСКТ, органы груАной кАетки.}

а - мегочный режим, аксиальная плоскость; б - медиастинальный режим, аксиальная плоскость; в - мультипланарная реконструкция. B S8 мевого мегкого определяется солидное образование неправицьной фрормы (стрелка), размерами 38 мм, неоднородной структуры за счет участков низкой плотности с неровными наружными контурами.

The scialogical picture of the mass taking into account the absence of foci in the surrounding tissue or cavities, was more consistent with lung cancer. To clarify the nature of the changes and staging, positron emission tomography was additionally performed, combined with computer tomography (PET-CT).

In PET-CT (Fig. 3) the picture of the metabolically active process in the S8 of the left lung (SUV - 4,3) was determined. No other metabolic active changes were detected.

According to the results of the medical consultation, taking into account the high probability of the oncological nature of the mass, a decision on surgical intervention was made. The patient underwent an extensive lower left lobectomy.

Histological examination of the surgical material revealed a conglomerate of caseous-necrotic foci with partial organization, calcination, and encapsulation, and its structure revealed micrometastasis of cancer originating from the vessel. The second histologist confirmed the diagnosis of tuberculosis: conglomerate tuberculosis with signs
The incidence of combination of tuberculosis and lung cancer is low given the common localization of the processes. It is important to emphasize that cases of squamous cell lung cancer are quantitatively prevalent among all types of combined tuberculosis [7].

The concept of simultaneous course of these two diseases couldn't find a sufficient justification for a long time. Initially, scientists believed that current diseases were not compatible with each other, but later the theory that tuberculosis is a predisposing factor for the development of lung cancer began to prevail [8].

It's known that inflammatory epithelial proliferations, squamous metaplasia and carcinoma in situ caused by tuberculosis and others chronic inflammations in lungs are not uncommon. Meantime, from a biological point of view, inflammatory and cancerous growths of the epithelium are different entities [9].

Even if they remain "precancerous" in terms of their histological differentiation, they do not necessarily turn into cancer; these are, more pre- 


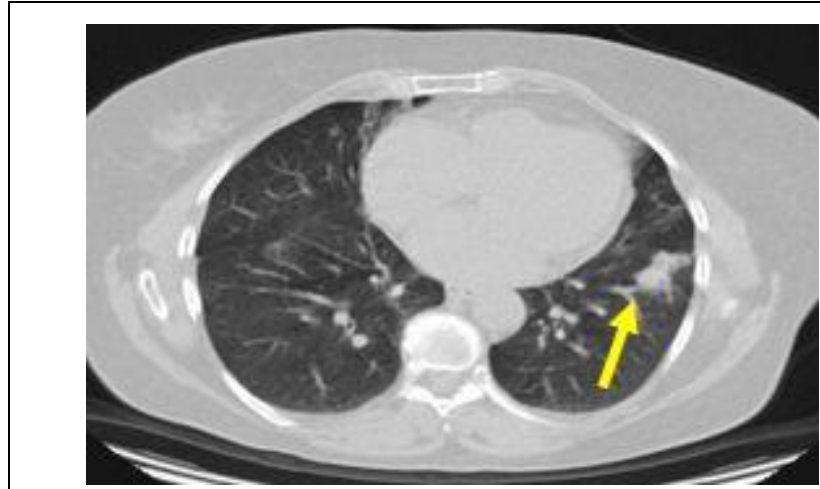

Fig. 3 a (Pис. 3 a)

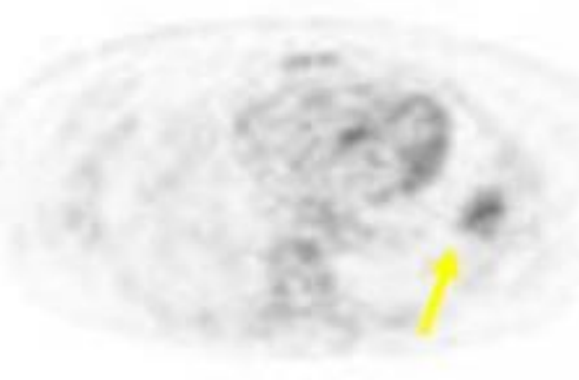

Fig. 3 b (Рис. 3 б)

\section{Рис. 3. РЕТ-СТ.}

In S8 of the left lung (arrow), a metabolically active process is determined (SUV - 4,3).

Fig. 3. ПЭТ-КТ.

B S8 мевого мегкого (стрелка) определяется метаболически активный процесс (SUV - 4,3$)$.

cisely, "conditionally precancerous" changes. Inflammatory growths of the epithelium are correlated with the body, and in no way have the ability to autonomously grow cancer cells. On the other hand, the phenotypic diversity of lung cancers in patients with tuberculosis (their localization in the central and then in the peripheral parts, histological features, etc.) as well as significant time intervals between the development of both, do not allow us to assume that there is a direct pathogenetic relationship between tuberculosis and lung cancer, which explains the higher incidence of the latter in patients with tuberculosis compared to the incidence of cancer in general population [10].

At present time it is believed that previously recognized independent processes can manifest themselves in various combinations and have a mutual influence on the course of the diseases. Most likely we are talking about the other, more complicated morphogenesis of lung pathology with the combination of tuberculosis and lung cancer.

Cases of coexistence of tuberculosis and lung cancer are basically registered with its upper lobe localization. A revelation of these processes at a single locus, in particular in lower left lobe of the lung is anecdotal reports which was reflected in the described clinical case [11].

Diagnostic difficulties in the asymptomatic course are due to a multidimensional similarity of the x-ray pattern of the diseases. According to the results of MSCT, some authors note the existence of round mass surrounding intact lung tissue. The presence of calcinations and cavities in the pathological foci could be determined in both tuberculo-

\section{References:}

1. Panchenko I.N., Gavrilov P.V., Archakova L.I. The importance of fluorographic examination in identifying various forms and phases of pulmonary tuberculosis (for example, the Komi Repub- sis and lung cancer. As the result, the current features do not allow us to get reliable information for performing qualitative and effective differential diagnostic of the described diseases [12].

Summing up, it's necessary to highlight the main emphasis - tuberculosis and lung cancer $\mathrm{x}$ ray patterns possess a large number of similarities. Moreover, according to PET-CT data, a significant accumulation of radioactive tracer was detected in the focus, which is not a diagnostic criterion on behalf of one or the other disease, since increased RP uptake may also be present in both tuberculosis and lung cancer. Therefore, morphological verification is required in many cases for final diagnosis [13, 4].

The current clinical case accurately demonstrates the uniqueness of the combined course of tuberculosis and lung cancer in an atypical localization.

\section{Conclusion.}

Summarizing the analyzed information, we can make a conclusion that the combination of tuberculosis and lung cancer remains an up-todate controversial issue in the medical community. Difficulties in diagnosing due to the possibility of these diseases' manifestation in poor symptoms and similarity of the X-ray patterns, as well as changes in the concepts of coexistence and mutual influence of these pathologies encourage interest in finding and choosing new optimal and effective diagnostic methods.

lic). Thoracic Radiology Syllabus International Conference and School for Doctors. Ed. prof. I.E. Tyurina. 2010. P. 220-221 (in Russian). 


\section{RUSSIAN ELECTRONIC JOURNAL OF RADIOLOGY}

2. Yablonsky P.K. Innovations in the diagnosis, treatment, prognosis and prevention of tuberculosis. Akademicheskij zhurnal Zapadnoj Sibiri 2018; 14 (6): 37-47 (in Russian).

3. Trofimova T.N., Mishchenko A.V.. Modern standards for the analysis of radiation images. Guides for doctors. St. Petersburg, 2017. 300 p. (in Russian).

4. Turin I.E. Solitary pulmonary lesions: differential diagnosis criteria. REJR 2013; 9 (3): 50-52 (in Russian).

5. Raznatouska O.M., Fedorets A.V., Khlystun V.M., et al. Difficulties of Diagnosis of the Central Endophytic Tumor of the Lungs Arising in the Background of Tuberculosis. Aktual'naya infektologiya. 2016; 1 (10): 44-47 (in Russian).

6. Trahtenberg A.H., Kolbanov K.I. Lung cancer. Atmosfera. Pul'monologiya i allergologiya. 2008; 4: 3-9 (in Russian).

7. Karashchuk N.P., Kiseleva M.V. Cancer and tuberculosis of the lung. Nauchnyj medicinskij vestnik YUgry. 2014; 1-2 (5-6): 71-73 (in Russian).

8. Ho JC, Leung CC. Management of co-existent tuberculosis and lung cancer. Lung Cancer. 2018; 122: 83-87.

9. Garshin V.G. Inflammatory growths of the epithelium, their biological significance and attitude to the problem of cancer.

\section{Список Аитературы:}

1. Панченко И.Н., Гаврилов П.В., Арчакова А.И. Значение флюорографического обследования в выявлении различных форм и фаз туберкулеза легких (на примере республики Коми). Торакальная радиология Силлабус Международной конферениии и школь для врачей. Под ред. проф. И.Е. Тюрина. 2010. С. 220-221.

2. Яблонский П.К. Инноваиии в диагностике, лечении, прогнозировании и профилактике туберкулеза. Академический журнал Западной Сибири 2018; 14 (6): 37-47.

3. Трофимова Т.Н., Мищенко А.В., Минько Б.А.. и др. Современные стандарты анализа лучевых изображений: руководство для врачей/под ред. проф. Т.Н. Трофимовой. СПб., 2017. $300 \mathrm{c}$.

4. Тюрин И.Е. Одиночные очаги в легких: критерии дифреренииальной диагностики. Российский электронный журнал лучевой диагностики. 2013; 3 (3): 50-52.

5. Разнатовская Е.Н., Федореи А.В., Хлыстун В.Н. и др. Трудности диагностики иентральной эндофитной опухоли легкого, возникшей на фоне туберкулеза. Актуальная инфектология. 2016; 1 (10): 44-47.

б. Трахтенберг А.Х., Колбанов К.И. Рак легкого. Атмосфрера. Пульмонология и аллергология. 2008; 4: 3-9.

7. Карашук Н.П., Киселева М.В. Рак и туберкулез легкого. Научный медииинский вестник Югры. 2014;1-2 (5-6): 71-73.

8. Ho JC, Leung CC. Management of co-existent tuberculosis
SPb., 2017 (in Russian).

10. Novickaya T.A., Dvorakovskaya I.V., Ariel' B.M., YAblonskij P.K. Tuberculosis and Lung Cancer. Medicinskij al'yans. 2019; S3: 230-231 (in Russian).

11. Byun HG, Yoo JY, Kim SJ, Lee OJ, Yoo MY. Coexistence of lung adenocarcinoma and pulmonary tuberculosis within a single lesion. Medicine. 2019; 98: 39.

12. Molodkin I.V., Yakunin A.G., Shayduk A.M., Konovalov V.K., Ostanin S.A., Leonov S.L., Borisenko O.V. The constitution system of diagnostic characters usingoutcome analysis of boundary circular-shaped masses in lungs. REJR. 2019; 9 (3): 79-85. DOI:10.21569/2222-7415-2019-9-3-79-85 (in Russian).

13. Tlostanova M.S., Tyutin L.A., Yablonsky P.K et al. 18F-FDG pet in the differential diagnosis of lung cancer. Luchevaya diagnostika i terapiya. 2012; 4 (3): 55-59 (in Russian).

14. Popova E., Avetisyan A., Tlostanova M., Blum N., Marfina G., Yablonsky P. Method of PET/CT in determinining the activity of tb inflammation in patients with pulmonary tuberculomas. European Respiratory Journal. 2014; 44 (S58): 2437.

and lung cancer. Lung Cancer. 2018; 122: 83-87.

9. Гаршин В.Г. Воспалительные разрастания эпителия, их биологическое значение и отночение $\kappa$ проблеме рака. СПб., 2017.

10. Новиикая Т.А., Двораковская И.В., Ариэль Б.М., Яблонский П.К. Туберкулез и рак легких. Медииинский альянс. 2019; 3: 230-231.

11. Byun HG, Yoo JY, Kim SJ, Lee OJ, Yoo MY. Coexistence of lung adenocarcinoma and pulmonary tuberculosis within a single lesion. Medicine. 2019; 98: 39.

12. Molodkin I.V., Yakunin A.G., Shayduk A.M., Konovalov V.K., Ostanin S.A., Leonov S.L., Borisenko O.V. The constitution system of diagnostic characters using outcome analysis of boundary circular-shaped masses in lungs. Российский электронный журнал лучевой диагностики. 2019; 9 (3): 79-85.

13. Тлостанова М.С., Тютин А.А., Яблонский П.К. и др. Позитронная эмиссионная томография с 18F-ФДГ в дифференииальной диагностике рака легкого. Аучевая диагностика и терапия. 2012; 4 (3): 55-59.

14. Popova E., Avetisyan A., Tlostanova M., Blum N., Marfina G., Yablonsky P. Method of PET/CT in determinining the activity of tb inflammation in patients with pulmonary tuberculomas. European Respiratory Journal. 2014; 44 (S58): 2437. 